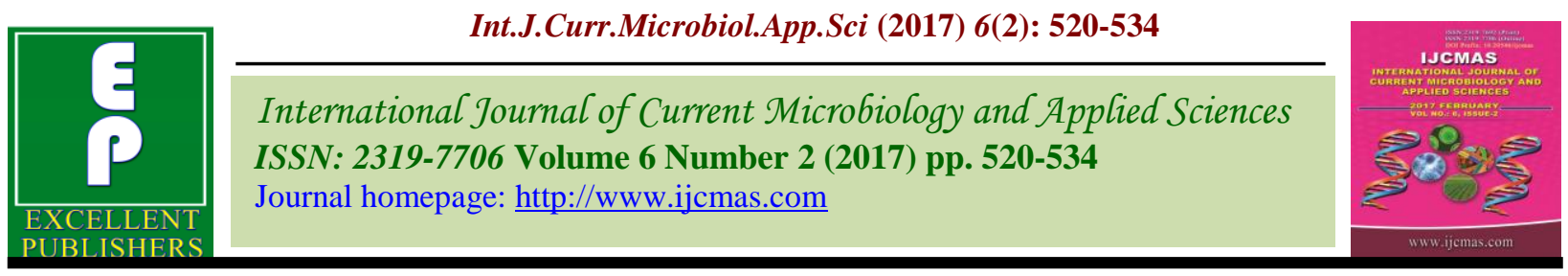

Original Research Article

http://dx.doi.org/10.20546/ijcmas.2017.602.059

\title{
Effect of Different Levels of Phosphorus and Sulphur on Growth and Nutrient Uptake of Green gram (Vigna radiata L.) under Teak (Tectona grandis $L_{\text {.) }}$ based Agroforestry System
}

\author{
Jaiveer Singh Dhewa ${ }^{1}$, Sameer Daniel $^{1}$ and Sulochana ${ }^{2}$ \\ ${ }^{1}$ Department of Agroforestry, Sam Higginbottom Institute of Agriculture, \\ Technology and Sciences, Allahabad-211007, India \\ ${ }^{2}$ Rajasthan College of Agriculture, Maharana Pratap University of Agriculture and \\ Technology, Udaipur (Raj) -313001, India \\ *Corresponding author
}

\section{A B S T R A C T}

Application of phosphorus and elemental sulphur is an important tool to obtain high yield of green gram (Vigna radiata L.) under teak based agroforestry system in kharif season 2014 and 2015. The overall goal of the present experiment was to assess the impacts of

\begin{tabular}{|c|}
\hline Keywords \\
\hline $\begin{array}{l}\text { Phosphorus, } \\
\text { Sulphur, } \\
\text { Agroforestry } \\
\text { system, Growth, } \\
\text { and uptake, } \\
\text { Green gram. }\end{array}$ \\
\hline Article Info \\
\hline $\begin{array}{l}\text { Accepted: } \\
\text { 15 January } 2017 \\
\text { Available Online: } \\
10 \text { February } 2017\end{array}$ \\
\hline
\end{tabular}
phosphorus and elemental sulphur application on green gram growth under teak based agroforestry system in eastern Uttar Pradesh, India. Green gram was grown in an alley cropping system, which integrates trees with grain crops. Specific objectives of the study were to: $(a)$ determine theeffect of phosphorus and sulphur on growth of green gram under teak based agroforestry system during Kharif season; $(b)$ evaluate the interaction effect between phosphorus and sulphur levels, if any $(c)$, to find the effect of phosphorus and sulphur levels on nutrient content and uptake by green gramunder teak based agroforestry system during kharif season. The impacts on green gram growth were assessed for different rates of phosphorus $(25,45$ and $65 \mathrm{~kg} / \mathrm{ha})$ and $\mathrm{S}(20,35$ and $50 \mathrm{~kg} / \mathrm{ha})$ under teak based agroforestry system during kharif season. The field experiment was laid out according to a factorial randomized block design with three replications of 9 treatment combinations. Application of phosphorus at $65 \mathrm{~kg} / \mathrm{ha}$ produced the best results in terms of the green gram growth attributes like plant height, number of trifoliate leaves/plant, dry matter accumulation, number of nodules/plant, CGR, RGR and NPKS content and uptake by crop compared with the phosphorus at $45 \mathrm{~kg} / \mathrm{h}$ and $25 \mathrm{~kg} / \mathrm{ha}$ under both condition open and teak based agroforestry system. However application sulphur at $50 \mathrm{~kg} / \mathrm{ha}$ also gives higher growth and nutrient content and uptake by the crop as compared with $\mathrm{S} 35 \mathrm{~kg} / \mathrm{ha}, \mathrm{S}$ $20 \mathrm{~kg} / \mathrm{ha}$ in both condition open and teak based agroforestry system.

\section{Introduction}

Pulses production is very low and become challenging problem against the requirement of increasing population of our country. The pulses availability per capita was $69.9 \mathrm{~g}$ in 1951 , by increasing in 1971 , it comes to $50 \mathrm{~g}$ and in 1982 remained only $40 \mathrm{~g}$ and in 2005, it was $27 \mathrm{~g}$. The availability of pulses is very negligible at present as against required $85 \mathrm{~g}$ day-1capita- 1 for balanced diet to recover this deficit of production. It is high time to cultivate pulses crops scientifically with increasing area (Patel et al., 2013). The 
United Nations, declared 2016 as "International Year of Pulses" (IYP) to heighten public awareness of the nutritional benefits of pulses as part of sustainable food production aimed at food security and nutrition. India is the largest producer $(25 \%$ of global production), consumer (27\% of world consumption) and importer (14\%) of pulses in the world. Pulses account for around 20 per cent of the area under food grains and contribute around 7-10 per cent of the total foodgrains production in the country (Mohanty and Satyasai, 2015).

Green gram (Vigna radiata L.) is cultivated in tropical and subtropical regions of Indiaas a summer (Kharif) rainfed crop (Anilakumar et al., 2010).Pulses are consumed all over the world; their consumption is higher in those parts of the world where animal proteins are scarce and expensive (Ofuya and Akhidue, 2005). Green gram commonly known as 'Moongbean'or 'Moong' contains 24.3 per cent protein fairly rich in carbohydrates and also contains small amount of riboflavin and thiamine, also rich in phosphorus and iron (Patel et al., 2013). It's also contains high quality of lysine $(4600 \mathrm{mg} / \mathrm{g} \quad \mathrm{N})$ and tryptophan $(60 \mathrm{mg} / \mathrm{g} \mathrm{N})$ and consumed as whole grain or as well as in the form of Dal for table purposes. Mungbean is supposed to be easily digestible and, hence preferred by patients. The sprouted sees of mungbean are rich in ascorbic acid (Vitamin C), riboflavin and thiamine (Choudhary, 2010)

Alley cropping is a type of agroforestry system in which seasonal crops are grown in between the rows of trees. There are several types of alley cropping systems depending upon different associations of trees and crops (Torquebiau, 2000). Teak (Tectona grandis L.) is the most important timber tree in India, especially for furniture making. The species belongs to family Lamiaceae and locally known as Sagwan. It fetches higher prices due to quality of timber. It can be grown in all parts of the country except dry western zone. Mostly it prefers a deep, fertile, well-drained deep alluvial soil. The sandy soil is considered to be the best soil texture for this tree. It fails to grow in the soil with $\mathrm{pH}$ below 6.5. Mr. Chatu Menon of Malabar (Kerala) is known as the father of teak plantation in India. He had raised more than a million teak plants in Kerala during 1842 - 1862 (Parameswarappa, 1995; Dotaniya et al., 2013).

The phosphorus requirements vary depending upon the nutrient content of the soil (Bose and Som, 1986). Phosphorus shortage restricts the plant growth and remains immature. Common diagnostic properties of phosphorus deficiency are a darker green leaf colour due to higher chlorophyll contents (often with red pigments from anthocyanins), reduced leaf extension and a higher root-to-shoot ratio, since root growth is much less affected by phosphorus deficiency than shoot growth (Wild, 1988; Marschner, 1995). A high phosphorus supply is needed for nodulation of legumes and hence phosphorus deficiency can also seriously reduce biological nitrogen fixation (Marschner, 1995). Phosphorus availability is a limiting factor for plant production in many agricultural soils (Fairhurst et al., 1999). In regions of the world without a history of use of phosphorus fertilizers, phosphorus deficiency is very common (Wild, 1988). A large portion of applied fertilizer phosphorus may be fixed to iron and aluminium oxides and is then not available for plant uptake (Pal et al., 2014). These facts make sound phosphorus management imperative, especially in situations where funds for fertilizer purchases are limited, as in tropical smallholder agriculture. Agro forestry techniques can help to overcome some of these constraints (Buresh, 1999). However, because of generally low phosphorus concentrations in mulch materials, low atmospheric inputs and low release by mineral weathering, adequate 
applications of phosphorus fertilizers are necessary in permanent agriculture to ensure economic and ecological sustainability (Buresh et al., 1997 and Newman, 1997). The deficiency of $S$, one of the fourth most important nutrient after N,P and K (McGrath et al., 1996; Walker and Dawson 2003; Matula 2004) is a major constraint to sustainable production of oilseed crops in many parts of the world including India (Saha et al., 2001; Biswas et al., 2003; Grant et al., 2003; Malhi and Gill, 2007). About 41\% of soils in India are deficient in $\mathrm{S}$, and yield of oilseed crops is adversely affected (Lakkineni and Abrol, 1992; Tewatia et al., 2007). Deficiency of $\mathrm{S}$ is also reported in soils of the Allahbad region of India (Singh, 2001; Ahmad et al., 2005; Singh and Kumar, 2012; Scherer, 2001, 2009). Deficiency of S adversely affects flowering, fruiting, and cupping of leaves, reddening of stems, petioles and stunted growth of oilseed crops (Salwa et al., 2010; Saha et al., 2001). The requirement of $\mathrm{S}$ is higher in oilseed crops due to its critical role in synthesis of oil and production of bold grains (Havlin et al., 2004; Malhi et al., 2007). Therefore, the sustainable production of oilseed crops (i.e., sesame) in acidic soils requires knowledge of the sitespecific rates of liming and $\mathrm{S}$ fertilization (Tiwari et al., 2000; Singh et al., 2011).

Research information on the conjunctive rate of phosphorus and $\mathrm{S}$ application under sitespecific conditions of growing green gram are not widely available, especially in an alley cropping system where pulses crops are grown in between the rows of fruit trees. Yet, this information is necessary to effectively sustain the productivity of the green gram while also alleviating $\mathrm{S}$ deficiency. Therefore, the present study was conducted to assess the impacts of application of phosphorus and Sulphur on growth, and nutrient content and uptake of green gram under teak (Tectona grandis L.) based agroforestry system and open condition of Allahbad.

\section{Materials and Methods}

\section{Experimental site}

A field experiment was conducted during Kharif season of 2014 and 2015. The experimental site is situated at Forest Nursery, School of Forestry and Environment, Sam Higginbottom Institute of Agriculture, Technology and Sciences (Deemed-To-BeUniversity) Allahabad, India. The Centre is situated at $25.41^{\circ} \mathrm{N}$ latitude and $81.84^{\circ} \mathrm{E}$ longitude and at an altitude of 98 meter sea level.

\section{Crop and climate}

Allahabad is situated at an elevation of $25.4^{\circ} \mathrm{N}$ latitude and $81.84^{\circ} \mathrm{E}$ longitude, and 98 meter above the mean sea level. It is lo0cated in the South-eastern part of Uttar Pradesh and has tropical to sub-tropical climate with extremes of summer and winter. During the winter months especially December and January, temperature drops down to as low as $5^{\circ} \mathrm{C}$ while in the summer temperature reaches above $45^{\circ} \mathrm{C}$, hot scorching winds (commonly known as Loo) is regular feature during the summers whereas there may be an occasional spell of frost during the winter. The annual rainfall is $1100 \mathrm{~mm}$ mostly during the monsoon autumn i.e. July to September, with a few occasional showers during the winter months.

\section{Soil analysis}

Soil samples were collected randomly from 0 $30 \mathrm{~cm}$ depth within each $10 \mathrm{~m}$ interval at the three physiographic positions of the experimental field prior to sowing and after harvest of the crop. Soil samples were air dried, gently ground and passed through $2 \mathrm{~mm}$ sieve.

The plow layer contains $245.08 \mathrm{~kg} / \mathrm{ha}$ alkaline permanganate oxidizable N (Subbiah and 
Asija, 1956), $25.30 \mathrm{~kg} / \mathrm{ha}$ of available $\mathrm{P}$ extracted by $0.5 \mathrm{M} \mathrm{NaHCO}_{3}$ at $\mathrm{pH} 8.5$ (Olsen and Sommers, 1982), $128.60 \mathrm{~kg} / \mathrm{ha}$ of available $\mathrm{K}$ as determined by the flame photometer method with $1 \mathrm{~N} \mathrm{KCl}$ and titrating sued $0.05 \mathrm{~N} \mathrm{NaOH}$ (McLean, 1982), $13 \mathrm{~kg} / \mathrm{ha}$ of $\mathrm{S}$ as determined by the turbity method (Chesnin and Yein, 1950), soil organic carbon (SOC) concentration of $0.31 \%$ and converted to SOC stock by using the American Society for Testing and Materials (ASTM, 2000), and soil $\mathrm{pH}$ (7.45) as determined in 1:2 (soil: water) extract of the soil using deionized water, and electrical conductivity (EC) 0.034 $\mathrm{dS} / \mathrm{m}$ at $25^{\circ} \mathrm{C}$ in $1: 2$ (soil : water) suspension using $0.01 \mathrm{M}$ potassium chloride solution (Reeuwijk, 2002).

\section{Treatment details and field layout}

The field experiment was laid out according to a factorial randomized block design with three replications. The experiment comprised of 9 treatment combinations consisting three levels of phosphorus $(25,45$ and $65 \mathrm{~kg} / \mathrm{ha})$ and $\mathrm{S}$ (20, 35 and $50 \mathrm{~kg} / \mathrm{ha})$. Green gram was grown within the alleys of 12-years old teak (Tectonagraindis L.) plantation. The teak trees were planted at a spacing of $9 \times 3 \mathrm{~m}$. Green gram was sown on $30 \mathrm{~cm}$ between the rows and $10 \mathrm{~cm}$ spacing within the plants between the teak trees.

The row of green gram next to the guava trees was $100 \mathrm{~cm}$ away and there were a total of 10 rows of green gram within the alley of two rows of teak. The gross and net plot size was $3 \times 4 \mathrm{~m}, 2.10 \times 3 \mathrm{~m}$, respectively. The distance between the teak and green gram row was $1 \mathrm{~m}$ on both sides. The crop also grown in open condition with same spacing and gross or net plot size.

\section{Variety}

Samrat is a recommended variety of green gram for cultivation in summer and Kharif season and matures in 60-65 days. Plant height is $40-45 \mathrm{~cm}$. Growth habit is erect. Pod shape is long slender, medium in size. Pod length is $6.5 \mathrm{~cm}$ and number of seed pod $^{-1}$ is 10-11. 1000 grains weight is $38-40 \mathrm{~g}$. The grain is green and medium bold. Yield potential is $09-10 \mathrm{q} \cdot \mathrm{ha}^{-1}$.

\section{Cultural practices and observations}

Phosphorus $\left(\mathrm{P}_{2} \mathrm{O}_{5}\right)$ and elemental sulphur $\left(\mathrm{S}^{0}\right.$ S) were applied as per treatments 30 and 15 days before sowing, respectively. Phosphorus $(25,45$ and $65 \mathrm{~kg} / \mathrm{ha})$ and $\mathrm{S}(20,35$ and 50 $\mathrm{kg} / \mathrm{ha}$ ) was drilled at the depth of $5 \mathrm{~cm}$. as single super phosphate and elemental sulphur, respectively. The fertilizer was drilled in furrows at $5 \mathrm{~cm}$ below the seedling depths before sowing. The green gram was seeded at the recommended seed rate of $=15 \mathrm{~kg} / \mathrm{ha}$, and at $2.5 \mathrm{~cm}$ soil depth. The seeds were covered by the soil from the other side of furrow. At 15 days after sowing (DAS), thinning was done to maintain the desired plant population. Periodic hand weeding was done as and when needed. Growth attributes are recorded at different stage of crop like plant height $(\mathrm{cm})$, number of trifoliate leaves/plant, number of branches/plant, leaf area index $(\mathrm{cm})$, dry matter accumulation (g/plant), number of nodules/plant, number of pods at 50 and 100 percent maturity, respectively. Nutrient content and total uptake by crop also recorded.

\section{Statistical analysis}

The Microsoft Excel was used as a statistical software package for analyzing the data for the analysis of variance and other statistical parameters (McCullough and Wilson 2005).

Critical difference (CD) values at $\mathrm{p}=0.05$ were used to determine the significance of differences between mean values of treatments. The standard level of significance used to justify a claim of a statistically 
significant effect is 0.05 (Draper and smith, 1998).

\section{Results and Discussion}

\section{Effect of phosphorus levels}

Significantly higher pooled values of growth parameters year 2014 and 2015 under shade (teak) were obtained for the phosphorus application at $65 \mathrm{~kg} / \mathrm{ha}$ in comparison with other treatment. These parameters included plant height $(\mathrm{cm})$ at 20DAS (14.08), 40DAS (23.44) and at harvest (44.47), number of trifoliate leaves/plant at 20DAS, 40DAS and at harvest was recorded 1.82, 11.21, 9.31 number of branches/plant at 20DAS (1.91) and 40 DAS (6.26) (Table 1), leaf area index $(\mathrm{cm})$ at 20DAS (1.23), 40DAS (2.41) and at harvest (2.0) number of nodules/plant at 20 DAS and 40DAS was recorded 6.46 and 14.91, respectively, and crop growth rate at 20-40DAS (0.456) and 40- 60DAS (0.268) (Table 2), relative growth rate at 20-40DAS and 40-60DAS was recorded 1.241 and 0.730 and dry matter accumulation (g/plant) at 20 DAS (5.61), 40DAS (15.09) and at harvest (20.46), number of pods at 50 and 100 percent maturity was recorded 9.71 and 12.40 respectively (Table 3 ).

Moreover, nutrient content (\%) and uptake $(\mathrm{kg} / \mathrm{ha})$ by crop were also recorded the application phosphorus found significantly higher value in caparison of the other treatment. These parameters included nitrogen content in grain and straw $(2.37,1.38)$, phosphorus content in grain and straw $(0.35$, 0.189 ), potassium content in grain and straw $(0.50,1.04)$, sulphur content in grain and straw (0.21, 0.082) (Table 4), respectively. Moreover the total N, P, K and S uptake was recorded (36.90, 5.29, 20.29 and 2.62), respectively (Table 5).

The data shows that significantly higher pooled values of growth parameters year 2014 and 2015 under open condition were obtained for the phosphorus application at $65 \mathrm{~kg} / \mathrm{ha}$ in comparison with other treatment. These parameters included plant height $(\mathrm{cm})$ at 20DAS (16.27), 40DAS (31.22) and at harvest (51.19), number of trifoliate leaves/plant at 20DAS, 40DAS and at harvest was recorded 4.10, 20.33, 11.64 number of branches/plant at 20DAS (3.96) and 40 DAS (11.57) (Table 1), leaf area index $(\mathrm{cm})$ at 20DAS (3.36), 40DAS (5.10) and at harvest (5.94) number of nodules/plant at 20 DAS and 40DAS was recorded 2.63 and 24.00, respectively, and crop growth rate at 2040DAS (0.926) and 40- 60DAS (0.128) (Table 2), relative growth rate at 20-40DAS and 40-60DAS was recorded 2.52 and 0.128 and dry matter accumulation (g/plant) at 20 DAS(6.70), 40DAS (25.22) and at harvest(27.78), number of pods at 50 and 100 percent maturity was recorded 12.71 and 14.72 respectively (Table 3). Moreover, nutrient content $(\%)$ and uptake $(\mathrm{kg} / \mathrm{ha})$ by crop were also recorded the application phosphorus at $65 \mathrm{~kg} / \mathrm{ha}$ found significantly higher value in caparison of the other treatment.

These parameters included nitrogen content in grain and haulm $(3.68,1.61)$, phosphorus content in grain and straw $(0.69,0.25)$, potassium content in grain and straw (0.85, $1.56)$, sulphur content in grain and straw $(0.48,0.20)$ (Table 4), respectively. Moreover the total $\mathrm{N}, \mathrm{P}, \mathrm{K}$ and $\mathrm{S}$ uptake was recorded (100.33, 17.12, 66.56 and 12.57), respectively (Table 5). Similar results were reported Patil et al., (2011); Ali et al., (2010); Dhewa et al., (2015); Dhewa et al., (2017). In general, the overall increase in growth of summer mungbean with $\mathrm{P}$ application can be ascribed to its pivotal role in several physiological and biochemical processes necessary for crop growth and development. It is an established fact that among nutrients, $\mathrm{P}$ is the most important for exploiting genetic potentials of the crop/variety (Tisdale et al., 2003). But in 
the shade condition the growth attributes and nutrient uptake and content found than open condition due interaction between the teak plant and alley crop like light limitation, nutrient use efficiency, water requirement and defoliation of the teak plant because their leaf are very large and not easily decomposable that effect the alley crop germination and plant growthKumar et al., (2015); Prasad et al., (2014). Mutanal (1998) reported that a significant decrease in plant height and leaf area of groundnut when grown in teak based agroforestry systems especially under rainfed conditions. The reason for this paucity of information appears to be the dominance of entrenched notion that trees and annual crops are mutually incompatible (Nadagoud, 1990). Reduced plant height in agroforestry system compared to sole crop could be attributed to reduction in cell turgidity as a result of stress imposed due to competition for water, which lead to decrease in cell elongation and decreased plant height.

The observations of the present study are in line with those of Kramer (1959) who observed reduced cell elongation due to reduced cell turgidity which decreased not only the size of the plants but also the yield. It is observed that the number of leaves was greatly influenced by intercropping with teak trees indicating beneficial effects of complementing with teak. When reduction in leaf size is more, decreases the photosynthetic surface and finally affected the yield (Padeyannavar, 2002 and Venkata Rao, 2006; Mutanal, 1998).

\section{Effect of sulphur levels}

The data showed that significantly higher pooled values of growth parameters year 2014 and 2015 under shade (teak) were obtained for the sulphur application at $50 \mathrm{~kg} / \mathrm{ha}$ in comparison with other treatment.

These parameters included plant height $(\mathrm{cm})$ at 20DAS (12.50), 40DAS (20.80) and at harvest (39.42), number of trifoliate leaves/plant at 20DAS, 40DAS and at harvest was recorded 1.72, 9.97, 8.27 number of branches/plant at 20DAS (1.70) and 40 DAS (5.57) (Table 1), leaf area index $(\mathrm{cm})$ at 20DAS (1.09), 40DAS (2.13) and at harvest (1.77) number of nodules/plant at 20 DAS and 40DAS was recorded 5.71 and 13.24, respectively, and crop growth rate at 4060DAS (0.205) but 20-40 DAS found non significant in both the year (Table 2), relative growth rate at 40-60DAS was recorded 0.559 but 20-40 DAS found non -significant in both the year and dry matter accumulation (g/plant) at 20 DAS (5.16), 40DAS (13.35) and at harvest (17.46), number of pods at 50 and 100 percent maturity was recorded 8.63 and 11.01 respectively (Table 3). Moreover, nutrient content $(\%)$ and uptake $(\mathrm{kg} / \mathrm{ha})$ by crop were also recorded the application sulphur at $50 \mathrm{~kg} / \mathrm{ha}$ found significantly higher value in comparison of the other treatment. These parameters included nitrogen content in grain and haulm $(2.12,1.22)$, phosphorus content in grain and haulm $(0.31,0.168)$, potassium content in grain and haulm $(0.43$, 0.92), sulphur content in grain and haulm $(0.18,0.073)$, respectively (Table 4). Moreover the total N, P, K and S uptake was recorded (30.02, 4.32, 16.47 and 2.14), respectively (Table 5). The data showed Significantly higher pooled values of growth parameters year 2014 and 2015 under open condition were obtained for the sulphur application at $50 \mathrm{~kg} / \mathrm{ha}$ in comparison with other treatment. These parameters included plant height $(\mathrm{cm})$ at 20DAS (14.45), 40DAS (27.71) and at harvest (45.36), number of trifoliate leaves/plant at 20DAS, 40DAS and at harvest was recorded 3.65, 18.04, 10.33, number of branches/plant at 20DAS (3.51) and 40 DAS (10.27) (Table 1), leaf area index (cm) at 20DAS (2.99), 40DAS (4.53) and at harvest (5.28) number of nodules/plant at 20 DAS and 40DAS was recorded 2.33 and 21.27, respectively. 
Table.1 Effect of phosphorus and sulphur levels on plant height $(\mathrm{cm})$, number of trifoliate leaves/plant and number of branches/plant of kharif green gram(pooled data 2014 and 2015)

\begin{tabular}{|c|c|c|c|c|c|c|c|c|c|c|c|c|c|c|c|c|}
\hline \multirow{3}{*}{$\begin{array}{l}\text { Treat- } \\
\text { ment }\end{array}$} & \multicolumn{6}{|c|}{ Plant height $(\mathbf{c m})$} & \multicolumn{6}{|c|}{ Number of trifoliate leaves/plant } & \multicolumn{4}{|c|}{ Number of branches /plant } \\
\hline & \multicolumn{3}{|c|}{$\begin{array}{l}\text { Pooled Under shade } \\
\text { 2014-2015 }\end{array}$} & \multicolumn{3}{|c|}{$\begin{array}{l}\text { Pooled Under Open } \\
\text { 2014-2015 }\end{array}$} & \multicolumn{3}{|c|}{$\begin{array}{l}\text { Pooled Under shade } \\
\text { 2014-2015 }\end{array}$} & \multicolumn{3}{|c|}{$\begin{array}{l}\text { Pooled Under Open } \\
\text { 2014-2015 }\end{array}$} & \multicolumn{2}{|c|}{$\begin{array}{l}\text { Pooled Under } \\
\text { shade 2014- } \\
2015\end{array}$} & \multicolumn{2}{|c|}{$\begin{array}{c}\text { Pooled Under } \\
\text { Open 2014- } \\
2015\end{array}$} \\
\hline & $\begin{array}{c}20 \\
\text { DAS } \\
\end{array}$ & $\begin{array}{c}40 \\
\text { DAS }\end{array}$ & $\begin{array}{c}\text { At } \\
\text { harvest }\end{array}$ & $\begin{array}{c}20 \\
\text { DAS } \\
\end{array}$ & $\begin{array}{c}40 \\
\text { DAS }\end{array}$ & $\begin{array}{c}\text { At } \\
\text { harvest }\end{array}$ & $\begin{array}{c}20 \\
\text { DAS } \\
\end{array}$ & $\begin{array}{c}40 \\
\text { DAS }\end{array}$ & $\begin{array}{c}\text { At } \\
\text { harvest }\end{array}$ & $\begin{array}{c}20 \\
\text { DAS } \\
\end{array}$ & $\begin{array}{c}40 \\
\text { DAS } \\
\end{array}$ & $\begin{array}{c}\text { At } \\
\text { harvest }\end{array}$ & $\begin{array}{c}40 \\
\text { DAS } \\
\end{array}$ & $\begin{array}{c}\text { At } \\
\text { harvest }\end{array}$ & $\begin{array}{c}20 \\
\text { DAS } \\
\end{array}$ & $\begin{array}{c}\text { At } \\
\text { harvest }\end{array}$ \\
\hline \multicolumn{17}{|c|}{ Phosphorus Level (kg/ha) } \\
\hline 25 & 9.23 & 15.36 & 29.09 & 10.67 & 20.43 & 33.42 & 1.34 & 7.34 & 6.11 & 2.69 & 13.31 & 7.62 & 1.26 & 4.11 & 2.59 & 7.58 \\
\hline 45 & 12.08 & 20.06 & 38.02 & 13.95 & 26.71 & 43.70 & 1.65 & 9.62 & 8.01 & 3.53 & 17.40 & 9.96 & 1.65 & 5.39 & 3.39 & 9.91 \\
\hline 65 & 14.08 & 23.44 & 44.47 & 16.27 & 31.22 & 51.19 & 1.82 & 11.21 & 9.31 & 4.10 & 20.33 & 11.64 & 1.91 & 6.26 & 3.96 & 11.57 \\
\hline SEm \pm & 0.20 & 0.33 & 0.62 & 0.23 & 0.43 & 0.702 & 0.04 & 0.16 & 0.13 & 0.059 & 0.281 & 0.162 & 0.03 & 0.09 & 0.055 & 0.165 \\
\hline $\begin{array}{l}\text { CD } \\
(P=0.05)\end{array}$ & 0.59 & 1.00 & 1.87 & 0.69 & 1.31 & 2.124 & 0.13 & 0.48 & 0.40 & 0.178 & 0.849 & 0.49 & 0.08 & 0.28 & 0.166 & 0.498 \\
\hline \multicolumn{17}{|c|}{ Sulphur Level (kg/ha) } \\
\hline 20 & 11.21 & 18.63 & 35.32 & 12.96 & 24.81 & 40.61 & 1.51 & 8.92 & 7.42 & 3.27 & 16.14 & 9.26 & 1.53 & 4.99 & 3.15 & 9.20 \\
\hline 35 & 11.67 & 19.42 & 36.83 & 13.48 & 25.84 & 42.34 & 1.58 & 9.29 & 7.74 & 3.41 & 16.86 & 9.63 & 1.59 & 5.20 & 3.28 & 9.59 \\
\hline 50 & 12.50 & 20.80 & 39.42 & 14.45 & 27.71 & 45.36 & 1.72 & 9.97 & 8.27 & 3.65 & 18.04 & 10.33 & 1.70 & 5.57 & 3.51 & 10.27 \\
\hline $\operatorname{SEm} \pm$ & 0.20 & 0.33 & 0.62 & 0.23 & 0.436 & 0.702 & 0.04 & 0.16 & 0.13 & 0.059 & 0.281 & 0.162 & 0.03 & 0.09 & 0.055 & 0.165 \\
\hline $\begin{array}{l}\text { CD } \\
(P=0.05)\end{array}$ & 0.59 & 1.00 & 1.87 & 0.69 & 1.317 & 2.124 & 0.13 & 0.48 & 0.40 & 0.178 & 0.849 & 0.49 & 0.08 & 0.28 & 0.166 & 0.498 \\
\hline
\end{tabular}


Table.2 Effect of phosphorus and sulphur levels on leaf area index $(\mathrm{cm})$, number of nodules/plant and crop growth rate ( $\mathrm{g}$ m2 day1) of kharif green gram (pooled data 2014 and 2015)

\begin{tabular}{|c|c|c|c|c|c|c|c|c|c|c|c|c|c|c|}
\hline \multirow{3}{*}{$\begin{array}{c}\text { Treat- } \\
\text { ment }\end{array}$} & \multicolumn{6}{|c|}{ Leaf Area Index $(\mathrm{cm})$} & \multicolumn{4}{|c|}{ Number of nodules/plant } & \multicolumn{4}{|c|}{ Crop Growth Rate $\left(\mathrm{g} \mathrm{m}^{2}\right.$ day $\left.^{1}\right)$} \\
\hline & \multicolumn{3}{|c|}{$\begin{array}{c}\text { Pooled Under shade } \\
\text { 2014-2015 } \\
\end{array}$} & \multicolumn{3}{|c|}{$\begin{array}{c}\text { Pooled Under Open } \\
\text { 2014-2015 } \\
\end{array}$} & \multicolumn{2}{|c|}{$\begin{array}{c}\text { Pooled Under } \\
\text { shade 2014-2015 }\end{array}$} & \multicolumn{2}{|c|}{$\begin{array}{c}\text { Pooled Under } \\
\text { Open 2014-2015 }\end{array}$} & \multicolumn{2}{|c|}{$\begin{array}{c}\text { Pooled Under } \\
\text { shade 2014-2015 }\end{array}$} & \multicolumn{2}{|c|}{$\begin{array}{l}\text { Pooled Under } \\
\text { Open 2014-2015 }\end{array}$} \\
\hline & $\begin{array}{c}20 \\
\text { DAS }\end{array}$ & $\begin{array}{c}40 \\
\text { DAS }\end{array}$ & $\begin{array}{c}\text { At } \\
\text { harvest }\end{array}$ & $\begin{array}{c}20 \\
\text { DAS }\end{array}$ & $\begin{array}{c}40 \\
\text { DAS }\end{array}$ & $\begin{array}{c}\text { At } \\
\text { harvest }\end{array}$ & $\begin{array}{c}20 \\
\text { DAS }\end{array}$ & $\begin{array}{c}40 \\
\text { DAS }\end{array}$ & $\begin{array}{c}20 \\
\text { DAS }\end{array}$ & $\begin{array}{c}40 \\
\text { DAS }\end{array}$ & $\begin{array}{l}20-40 \\
\text { DAS }\end{array}$ & $\begin{array}{l}40-60 \\
\text { DAS }\end{array}$ & $\begin{array}{c}\text { 20-40 } \\
\text { DAS }\end{array}$ & $\begin{array}{l}40-60 \\
\text { DAS }\end{array}$ \\
\hline \multicolumn{15}{|c|}{ Phosphorus Level (kg/ha) } \\
\hline 25 & 0.81 & 1.58 & 1.30 & 2.21 & 3.36 & 3.90 & 4.21 & 9.78 & 1.72 & 15.68 & 0.332 & 0.058 & 0.605 & 0.084 \\
\hline 45 & 1.06 & 2.06 & 1.70 & 2.89 & 4.38 & 5.12 & 5.53 & 12.78 & 2.26 & 20.52 & 0.411 & 0.166 & 0.791 & 0.110 \\
\hline 65 & 1.23 & 2.41 & 2.00 & 3.36 & 5.10 & 5.94 & 6.46 & 14.91 & 2.63 & 24.00 & 0.456 & 0.268 & 0.926 & 0.128 \\
\hline SEm \pm & 0.018 & 0.037 & 0.03 & 0.048 & 0.072 & 0.083 & 0.09 & 0.21 & 0.037 & 0.332 & 0.010 & 0.013 & 0.013 & 0.002 \\
\hline $\begin{array}{l}\text { CD } \\
(P=0.05)\end{array}$ & 0.055 & 0.111 & 0.091 & 0.144 & 0.216 & 0.25 & 0.28 & 0.63 & 0.111 & 1.005 & 0.031 & 0.039 & 0.039 & 0.005 \\
\hline \multicolumn{15}{|c|}{ Sulphur Level(kg/ha) } \\
\hline 20 & 0.98 & 1.92 & 1.59 & 2.68 & 4.07 & 4.76 & 5.14 & 11.87 & 2.09 & 19.06 & 0.392 & 0.119 & 0.735 & 0.102 \\
\hline 35 & 1.02 & 1.99 & 1.64 & 2.79 & 4.23 & 4.93 & 5.34 & 12.36 & 2.19 & 19.88 & 0.398 & 0.169 & 0.767 & 0.106 \\
\hline 50 & 1.09 & 2.13 & 1.77 & 2.99 & 4.53 & 5.28 & 5.71 & 13.24 & 2.33 & 21.27 & 0.410 & 0.205 & 0.821 & 0.114 \\
\hline SEm \pm & 0.018 & 0.037 & 0.03 & 0.048 & 0.072 & 0.083 & 0.09 & 0.21 & 0.037 & 0.332 & 0.010 & 0.013 & 0.013 & 0.002 \\
\hline $\begin{array}{l}\text { CD } \\
(P=0.05)\end{array}$ & 0.055 & 0.111 & 0.091 & 0.144 & 0.216 & 0.25 & 0.28 & 0.63 & 0.111 & 1.005 & NS & 0.039 & 0.039 & 0.005 \\
\hline
\end{tabular}

DAS= Days after sowing; NS= Non significant 
Table.3 Effect of phosphorus and sulphur levels on dry matter accumulation (g/plant), relative growth rate (mg g-1 day-1) and number of pods at 50 and 100 per cent maturity of kharif green gram (pooled data 2014 and 2015)

\begin{tabular}{|c|c|c|c|c|c|c|c|c|c|c|c|c|c|c|}
\hline \multirow{3}{*}{$\begin{array}{l}\text { Treat- } \\
\text { ment }\end{array}$} & \multicolumn{6}{|c|}{ Dry matter accumulation (g/plant) } & \multicolumn{4}{|c|}{ Relative growth rate $\left(\mathrm{mg} \mathrm{g}^{-1}\right.$ day $\left.^{-1}\right)$} & \multicolumn{4}{|c|}{$\begin{array}{c}\text { Number of pods at } 50 \text { and } 100 \text { per } \\
\text { cent maturity }\end{array}$} \\
\hline & \multicolumn{3}{|c|}{$\begin{array}{l}\text { Pooled Under shade } \\
\text { 2014-2015 }\end{array}$} & \multicolumn{3}{|c|}{$\begin{array}{l}\text { Pooled Under Open } \\
\text { 2014-2015 }\end{array}$} & \multicolumn{2}{|c|}{$\begin{array}{l}\text { Pooled Under } \\
\text { shade 2014-2015 }\end{array}$} & \multicolumn{2}{|c|}{$\begin{array}{l}\text { Pooled Under } \\
\text { Open 2014-2015 }\end{array}$} & \multicolumn{2}{|c|}{$\begin{array}{c}\text { Pooled Under } \\
\text { shade 2014-2015 }\end{array}$} & \multicolumn{2}{|c|}{$\begin{array}{c}\text { Pooled Under } \\
\text { Open 2014- } \\
2015 \\
\end{array}$} \\
\hline & $\begin{array}{c}20 \\
\text { DAS }\end{array}$ & $\begin{array}{c}40 \\
\text { DAS }\end{array}$ & $\begin{array}{c}\text { At } \\
\text { harves } \\
\mathbf{t}\end{array}$ & $\begin{array}{c}20 \\
\text { DAS }\end{array}$ & $\begin{array}{c}40 \\
\text { DAS }\end{array}$ & $\begin{array}{c}\text { At } \\
\text { harvest }\end{array}$ & $\begin{array}{l}20-40 \\
\text { DAS }\end{array}$ & $\begin{array}{l}40-60 \\
\text { DAS }\end{array}$ & $\begin{array}{l}20-40 \\
\text { DAS }\end{array}$ & $\begin{array}{l}40-60 \\
\text { DAS }\end{array}$ & $50 \%$ & $100 \%$ & $\mathbf{5 0 \%}$ & $100 \%$ \\
\hline \multicolumn{15}{|c|}{ Phosphorus Level (kg/ha) } \\
\hline 25 & 9.85 & 11.02 & 5.28 & 4.39 & 16.49 & 18.17 & 0.903 & 0.159 & 1.65 & 0.084 & 6.37 & 8.13 & 8.33 & 9.62 \\
\hline 45 & 12.88 & 16.20 & 6.96 & 5.75 & 21.57 & 23.76 & 1.119 & 0.451 & 2.15 & 0.110 & 8.34 & 10.62 & 10.88 & 12.59 \\
\hline 65 & 15.09 & 20.46 & 7.80 & 6.70 & 25.22 & 27.78 & 1.241 & 0.730 & 2.52 & 0.128 & 9.71 & 12.40 & 12.71 & 14.72 \\
\hline SEm \pm & 0.212 & 0.326 & 0.158 & 0.095 & 0.350 & 0.39 & 0.028 & 0.035 & 0.035 & 0.002 & 0.139 & 0.176 & 0.178 & 0.205 \\
\hline $\begin{array}{l}\text { CD } \\
(P=0.05)\end{array}$ & 0.642 & 0.987 & 0.477 & 0.286 & 1.058 & 1.17 & 0.084 & 0.106 & 0.105 & 0.005 & 0.42 & 0.532 & 0.539 & 0.619 \\
\hline \multicolumn{15}{|c|}{ Sulphur Level (kg/ha) } \\
\hline 20 & 11.98 & 14.36 & 6.40 & 5.34 & 20.03 & 22.07 & 1.068 & 0.323 & 2.00 & 0.102 & 7.73 & 9.87 & 10.12 & 11.68 \\
\hline 35 & 12.50 & 15.87 & 6.61 & 5.56 & 20.89 & 23.01 & 1.082 & 0.458 & 2.09 & 0.106 & 8.06 & 10.28 & 10.51 & 12.20 \\
\hline 50 & 13.35 & 17.46 & 7.04 & 5.95 & 22.37 & 24.64 & 1.114 & 0.559 & 2.23 & 0.114 & 8.63 & 11.01 & 11.29 & 13.06 \\
\hline SEm \pm & 0.212 & 0.326 & 0.158 & 0.095 & 0.350 & 0.39 & 0.028 & 0.035 & 0.035 & 0.002 & 0.139 & 0.176 & 0.178 & 0.205 \\
\hline $\begin{array}{l}\text { CD } \\
(P=0.05)\end{array}$ & 0.642 & 0.987 & 0.477 & 0.286 & 1.058 & 1.17 & NS & 0.106 & 0.105 & 0.005 & 0.42 & 0.532 & 0.539 & 0.619 \\
\hline
\end{tabular}

DAS= Days after sowing; NS= Non significant 
Table.4 Effect of phosphorus and sulphur levels on nitrogen, phosphorus, potassium and sulphur content on grain and haulm of kharif green gram (pooled data 2014 and 2015)

\begin{tabular}{|c|c|c|c|c|c|c|c|c|c|c|c|c|c|c|c|c|}
\hline \multirow{3}{*}{$\begin{array}{c}\text { Treat- } \\
\text { ment }\end{array}$} & \multicolumn{16}{|c|}{ NPKS content in grain and haulm } \\
\hline & \multicolumn{2}{|c|}{$\begin{array}{l}\text { Pooled Under } \\
\text { shade 2014-2015 }\end{array}$} & \multicolumn{2}{|c|}{$\begin{array}{l}\text { Pooled Under } \\
\text { Open 2014-2015 }\end{array}$} & \multicolumn{2}{|c|}{$\begin{array}{l}\text { Pooled Under } \\
\text { shade 2014-2015 }\end{array}$} & \multicolumn{2}{|c|}{$\begin{array}{c}\text { Pooled Under } \\
\text { Open 2014-2015 }\end{array}$} & \multicolumn{2}{|c|}{$\begin{array}{c}\text { Pooled Under } \\
\text { shade 2014-2015 }\end{array}$} & \multicolumn{2}{|c|}{$\begin{array}{c}\text { Pooled Under } \\
\text { shade 2014-2015 }\end{array}$} & \multicolumn{2}{|c|}{$\begin{array}{l}\text { Pooled Under } \\
\text { shade 2014-2015 }\end{array}$} & \multicolumn{2}{|c|}{$\begin{array}{l}\text { Pooled Under } \\
\text { Open 2014-2015 }\end{array}$} \\
\hline & $\begin{array}{c}\mathrm{N} \\
\text { content } \\
\text { grain }\end{array}$ & $\begin{array}{c} \\
\text { content } \\
\text { haulm }\end{array}$ & $\begin{array}{c}N \\
\text { content } \\
\text { grain }\end{array}$ & $\begin{array}{c}\mathbf{N} \\
\text { content } \\
\text { haulm }\end{array}$ & $\begin{array}{c}P \\
\text { content } \\
\text { grain }\end{array}$ & $\begin{array}{c}\mathbf{P} \\
\text { content } \\
\text { haulm } \\
\end{array}$ & $\begin{array}{c}\mathbf{P} \\
\text { content } \\
\text { grain }\end{array}$ & $\begin{array}{c}\text { P content } \\
\text { haulm }\end{array}$ & $\begin{array}{c}K \text { content } \\
\text { grain }\end{array}$ & $\begin{array}{c}\mathrm{K} \\
\text { content } \\
\text { haulm }\end{array}$ & $\begin{array}{c}K \\
\text { content } \\
\text { grain }\end{array}$ & $\begin{array}{c}\text { K content } \\
\text { haulm }\end{array}$ & $\begin{array}{c} \\
\text { content } \\
\text { grain }\end{array}$ & $\begin{array}{c}\text { S content } \\
\text { haulm }\end{array}$ & $\begin{array}{c}\mathrm{S} \text { content } \\
\text { grain }\end{array}$ & $\begin{array}{c}\text { S content } \\
\text { haulm }\end{array}$ \\
\hline \multicolumn{17}{|c|}{ Phosphorus Level (kg/ha) } \\
\hline 25 & 1.52 & 0.90 & 2.39 & 1.04 & 0.23 & 0.123 & 0.45 & 0.17 & 0.32 & 0.68 & 0.56 & 1.03 & 0.14 & 0.054 & 0.31 & 0.13 \\
\hline 45 & 2.00 & 1.18 & 3.14 & 1.38 & 0.30 & 0.16 & 0.59 & 0.22 & 0.41 & 0.89 & 0.73 & 1.34 & 0.18 & 0.071 & 0.41 & 0.17 \\
\hline 65 & 2.37 & 1.38 & 3.68 & 1.61 & 0.35 & 0.189 & 0.69 & 0.25 & 0.50 & 1.04 & 0.85 & 1.56 & 0.21 & 0.082 & 0.48 & 0.20 \\
\hline SEm \pm & 0.037 & 0.02 & 0.056 & 0.029 & 0.006 & 0.003 & 0.010 & 0.004 & 0.009 & 0.017 & 0.012 & 0.024 & 0.003 & 0.001 & 0.007 & 0.003 \\
\hline $\begin{array}{l}\text { CD } \\
(P=0.05)\end{array}$ & 0.111 & 0.059 & 0.17 & 0.086 & 0.017 & 0.008 & 0.030 & 0.011 & 0.027 & 0.053 & 0.036 & 0.071 & 0.009 & 0.004 & 0.02 & 0.01 \\
\hline \multicolumn{17}{|c|}{ Sulphur Level (kg/ha) } \\
\hline 20 & 1.84 & 1.10 & 2.90 & 1.28 & 0.28 & 0.15 & 0.55 & 0.20 & 0.40 & 0.81 & 0.68 & 1.24 & 0.16 & 0.066 & 0.38 & 0.16 \\
\hline 35 & 1.92 & 1.13 & 3.04 & 1.34 & 0.29 & 0.154 & 0.57 & 0.21 & 0.40 & 0.88 & 0.70 & 1.29 & 0.17 & 0.068 & 0.39 & 0.16 \\
\hline 50 & 2.12 & 1.22 & 3.27 & 1.41 & 0.31 & 0.168 & 0.61 & 0.22 & 0.43 & 0.92 & 0.75 & 1.40 & 0.18 & 0.073 & 0.42 & 0.17 \\
\hline SEm \pm & 0.037 & 0.02 & 0.056 & 0.029 & 0.006 & 0.003 & 0.010 & 0.004 & 0.009 & 0.017 & 0.012 & 0.024 & 0.003 & 0.001 & 0.007 & 0.003 \\
\hline $\begin{array}{l}\text { CD } \\
(P=0.05)\end{array}$ & 0.111 & 0.059 & 0.17 & 0.086 & 0.017 & 0.008 & 0.030 & 0.011 & 0.027 & 0.053 & 0.036 & 0.071 & 0.009 & 0.004 & 0.02 & 0.01 \\
\hline
\end{tabular}

DAS= Days after sowing 
Table.5 Effect of phosphorus and sulphur levels on Total uptake $(\mathrm{kg} / \mathrm{ha})$ of nitrogen, phosphorus, potassium and sulphur by grain and haulm of kharif green gram (pooled data 2014 and 2015)

\begin{tabular}{|c|c|c|c|c|c|c|c|c|}
\hline \multirow{3}{*}{$\begin{array}{c}\text { Treat- } \\
\text { ment }\end{array}$} & \multicolumn{8}{|c|}{ Total N, P, K, Suptake (kg/ha)grain and haulm } \\
\hline & \multicolumn{2}{|c|}{$\begin{array}{c}\text { Pooled Under shade 2014- } \\
2015\end{array}$} & \multicolumn{2}{|c|}{$\begin{array}{c}\text { Pooled Under Open } \\
\text { 2014-2015 }\end{array}$} & \multicolumn{2}{|c|}{$\begin{array}{c}\text { Pooled Under shade 2014- } \\
2015\end{array}$} & \multicolumn{2}{|c|}{ Pooled Under Open 2014-2015 } \\
\hline & $\begin{array}{c}\text { N Total } \\
\text { uptake } \\
\end{array}$ & $\begin{array}{l}\text { P Total } \\
\text { uptake }\end{array}$ & $\begin{array}{c}\text { N Total } \\
\text { uptake }\end{array}$ & $\begin{array}{l}\text { P Total } \\
\text { uptake }\end{array}$ & $\begin{array}{c}\text { K Total } \\
\text { uptake }\end{array}$ & $\begin{array}{l}\text { S Total } \\
\text { uptake }\end{array}$ & $\begin{array}{c}\text { K Total } \\
\text { uptake }\end{array}$ & S Total uptake \\
\hline \multicolumn{9}{|c|}{ Phosphorus Level(kg/ha) } \\
\hline 25 & 16.16 & 2.33 & 44.07 & 7.54 & 9.09 & 1.14 & 29.38 & 5.53 \\
\hline 45 & 27.10 & 3.91 & 74.53 & 12.80 & 15.07 & 1.92 & 49.57 & 9.36 \\
\hline 65 & 36.90 & 5.29 & 100.33 & 17.12 & 20.29 & 2.62 & 66.56 & 12.57 \\
\hline SEm \pm & 1.03 & 0.15 & 2.658 & 0.464 & 0.637 & 0.069 & 1.793 & 0.335 \\
\hline $\begin{array}{l}\text { CD } \\
(P=0.05)\end{array}$ & 3.10 & 0.44 & 8.039 & 1.403 & 1.93 & 0.21 & 5.421 & 1.014 \\
\hline \multicolumn{9}{|c|}{ Sulphur Level(kg/ha) } \\
\hline 20 & 23.91 & 3.46 & 66.83 & 11.47 & 13.34 & 1.69 & 44.56 & 8.39 \\
\hline 35 & 26.22 & 3.76 & 70.93 & 12.12 & 14.63 & 1.85 & 47.17 & 8.89 \\
\hline 50 & 30.02 & 4.32 & 81.17 & 13.88 & 16.47 & 2.14 & 53.78 & 10.18 \\
\hline SEm \pm & 1.03 & 0.15 & 2.658 & 0.464 & 0.637 & 0.069 & 1.793 & 0.335 \\
\hline $\begin{array}{l}\text { CD } \\
(P=0.05)\end{array}$ & 3.10 & 0.44 & 8.039 & 1.403 & 1.93 & 0.21 & 5.421 & 1.014 \\
\hline
\end{tabular}

DAS= Days after sowing 

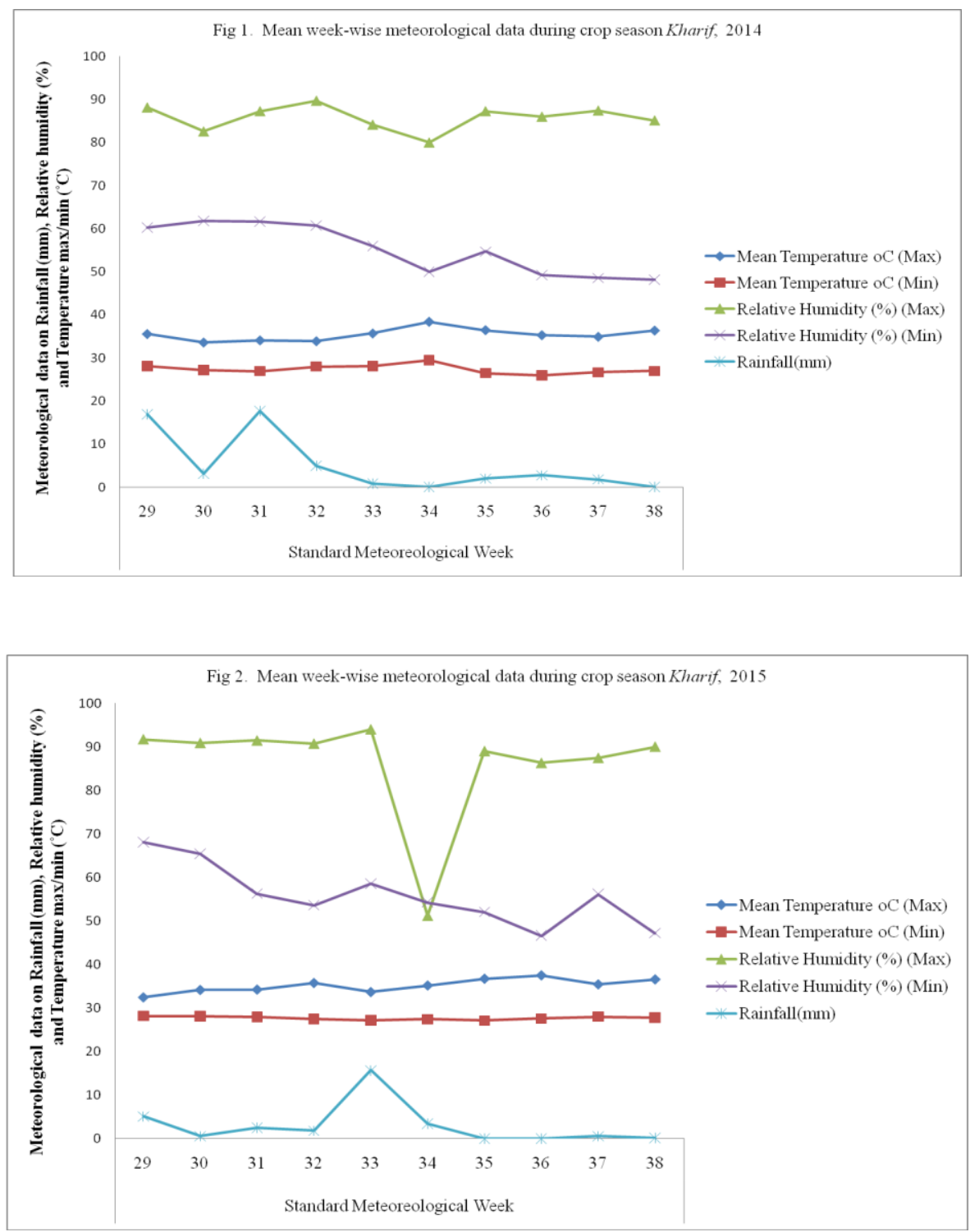

The crop growth rate at 20-40DAS (0.821) and 40- 60DAS (0.114) (Table 2), relative growth rate at 20-40DAS and 40-60DAS was recorded 2.23 and 0.114 and dry matter accumulation (g/plant) at 20 DAS (5.95), 40DAS (22.37) and at harvest (24.64), number of pods at 50 and 100 percent maturity was recorded 11.29 and 13.06 respectively (Table 3 ). Moreover, nutrient content $(\%)$ and uptake $(\mathrm{kg} / \mathrm{ha})$ by crop were also recorded the application sulphur at 50 $\mathrm{kg} / \mathrm{ha}$ found significantly higher value in comparison of the other treatment. These parameters included nitrogen content in grain and haulm $(3.27,1.41)$, phosphorus content in grain and straw $(0.61,0.22)$, potassium content in grain and straw $(0.75,1.40)$, sulphur content in grain and straw $(0.42$, 0.17 ), respectively (Table 4). Moreover the total $\mathrm{N}, \mathrm{P}, \mathrm{K}$ and $\mathrm{S}$ uptake was recorded $(81.17,13.88$, 53.78 and 10.18), respectively (Table 5). Similar result observed by De Datta et al., (2005); Hegde and Babu (2004); Hegde and Murthy (2005). The positive role of $S$ in formation of sulphalhydral group helping in building disulfide bond between the cysteine residues via oxidation and thus maintain the protein structure (Leustek and Saito, 1999). They also take part in transportation of sucrose and thereby take part in improving 
protein, oil content and yield in sesame (Fismes et al., 2000; Matula, 2004; Jan et al., 2010). Additionally, S also has the beneficial effect on the availability of nutrients to improving the growth and development of green gram crop.

In conclusion, this field experimentation suggested that the application of $65 \mathrm{~kg}$ phosphorus along with $50 \mathrm{~kg}$ sulphur/ha enhance growth and nutrient content and uptake of green gram crops grown under open condition but alley cropping with teak green gram growth and nutrient content and uptake are reduced but teak tree gives extra income as timber uses for best furniture of eastern Uttar Pradesh, India. However, these results are only indicative and require further experimentation to arrive at more consistent and final conclusion to be passed on the farmers.

\section{Acknowledgement}

Author is thankful to Dean of Department Agroforestry, School of Forestry and Environment for the providing necessary facility to carry out this work.

\section{References}

Ahmad, A., Khan, I., Anjum, N. A., Diva, I., Abdin, M. Z. and Iqbal, M. 2005. "Effect of timing of sulfur fertilizer application on growth and yield of rapeseed". J. Plant Nutri., 28(6):1049-59.

Ali, M.A., Abbas, G., Mohy-ud-Din, Q., Ullah, K., Abbas, G. and Ashan, M. 2010. Responce of mungbean (Vigna radiata) to phosphatic fertilizers under arid climate. J. Animal and Plant Sci., 20: 83-86.

Anilakumar, K.R., Pal, A., Khanum, F. and Bawa, A.S. 2010. Nutritional, medicinal and industrial uses of sesame (Sesamum indicum L.) seeds - an overview. Agriculturae Conspectus Scientificus, 75: 159-68.

ASTM. 2000. Standard test methods for moisture, ash, and organic matter of peat and other organic soils. Method D 2974-00. American Society for Testing and Materials, West
Conshohocken, PA.

Biswas, H., Rattan, R.K., Datta, S.P. and Singh, A.K. 2003. Adsorption and translocation of sulfur in some tropical acid soils. J Plant Nutrit. Soil Sci., 166: 519-24.

Bose, T.K. and Som, M.G. 1986.Vegetable crops in India, Naya Prokash, Calcutta-Six. India. 102.

Buresh, R.J. 1999. Phosphorus management in tropical agroforestry: current knowledge and research challenges. Agroforestry Forum, 9: 61-6.

Buresh, R.J., Smithson, P.C. and Hellums, D.T. 1997. Building soil phosphorus capital in Africa. In: Buresh, R.J., Sanchez, P.A. and Calhoun, F. (eds) Replenishing Soil Fertility in Africa. Soil Sci. Soc. America, Madison, Wisconsin.111-49.

Chaudhary, H.R. 2010. Integrated nutrient management in mungbean [Vigna radiata (L.)Wilczek]. M. Sc. (Agri.) thesis, Rajastan Agricultural University, Bikaner.

Chesnin, L., and Yein, C.H. 1950. Turbid metric determination of available sulfur. Soil Sci. Soc. America, Proceedings, 15: 149-51.

De Datta, S.K., Buresh, R.J. and Mamaril, C.P. 2005. Increasing nutrient-use efficiency in rice with changing needs.Nutrient Cycling in Agro- ecosystems, 26: 157-67.

Dhewa, J.S., Singh, Y., Sulochana and Singh, P. 2017. Effect of Phosphorus Levels and PSB on Productivity and Nutrient Uptake of Green Gram [Vigna radiata (L.) Wilczek] under Custard Apple (Annona Squamosa) Based on Agri-Horti System. Environ. Ecol., 35(1A): 358-362.

Dhewa, J.S., Yashwant, S., Sulochana and Bajia, R. 2015. Effect of phosphorus levels and psb on growth indices and yield of green gram [Vigna radiata (1.) Wilczek] under custard apple (Annona squamosa) based on agri- horti system. The Bioscan, 10(3): 1317-1320

Dotaniya, M.L., Meena, V.D., Lata, M. and Meena, H.P. 2013. Teak Plantation-A Potential Source of Income Generation, Popular Kheti, 1(3): 61-63.

Draper, N.R. and Smith, H. 1998. Applied Regression Analysis, 3rd ed., New York, John Wiley.

Fairhurst, T., Lefroy, R., Mutert, E. and Batjes, N. 1999. The importance, distribution and causes of phosphorus deficiency as a constraint to crop production in the tropics. Agroforestry Forum, 9: 2-7. 
Fismes, J., Vong, P. C. Gucker, A. and Frossard, E. 2000. Influence of $\mathrm{S}$ on apparent $\mathrm{N}$-use efficiency, yield and quality of oilseed rape (Brassica napusL.) grown on a calcareous soil. European J. Agronomy, 12: 127-41.

Grant, C.A., Clayton, G.W. and Johnston, A.M. 2003. Sulphur fertilizer and tillage effects on canola seed quality in the black soil zone of Western Canada. Canadian J. Plant Sci., 83: 745-58.

Havlin, J.L., Beaton, J.D. Tisdale, S.L. and Nelson, W.L. 2004. Soil fertility and fertilizers, an introduction to nutrient management. Singapore: Pearson Education, Pp 34-39.

Hegde, D.M. and Murthy, I.Y.L.N. 2005. Management of secondary nutrients: achievements and challenges. Indian $J$. Fertilizers, 1: 93-10.

Hegde, D.M. and Sudhakara Babu, S.N. 2004. Role of balanced fertilization in improving crop yield and quality. Fertilizer News, 49: I 03-31

Hüttemann, M., Lee, I., Samavati, L., Yu, H. and Doan, J.W. 2007 Regulation of Mitochondrial Oxidative Phospho- rylation through Cell Signaling. Biochimica et Biophysica Acta (BBA)-Mol. Cell Res., 1773: 1701-1720.

Jan, A., Ahmad, G., Arif, M., Jan, M.T. and Marwat, K.B. 2010. "Quality parameters of canola as affected by nitrogen and sulfur fertilization". J. Plant Nutri., 33(3): 381-90.

Kramer, P.J. 1959. The role of water in physiology of plants. Adv. Agron., 11: 51-70.

Kumar, P., Pandey, S.K. and Kumar, P. 2015. Effect of Different Phosphorus Levels on Nutrient Content, Uptake and Economics of Urd bean under Custard Apple based Agri-Horti System. J. Agri. Search, 2(2): 88-93.

Lakkineni, K.C., and Abrol, Y.P. 1992. "S requirement of rapeseed-mustard, groundnut and wheat: a comparative assessment," $J$. Agronomy and Crop Sci., 169(4): 281-85.

Leustek, T. and Saito. K. 1999. Sulfate transport and assimilation in plants. Plant Physiol., 120: 637-44.

Malhi, S.S. and Gill, K.S. 2007. "Interactive effects of $\mathrm{N}$ and $\mathrm{S}$ fertilizers on canola yield and seed quality on S-deficient Gray Luvisol soils in northeastern Saskatchewan," Canadian J. Plant Sci., 87(2): 211-22.

Marschner, H. 1995. Mineral Nutrition of Higher Plants. Academic Press, London, 889

Matula, J. 2004. Barley response to the soil reserve of $\mathrm{S}$ and ammonium sulphate in short-term experiments under controlled conditions of cultivation. Plant Soil and Environ., 50: 23542.

McCullough, B.D. and Wilson, B. 2005. Computational Statistics \& Data Analysis, 49: 1244-52.

McGrath, P.J., Nunes, E.V., Stewart, J.W., Goldman, D., Agosti, V., Ocepek-Welikson, K. and Quitkin, F.M. 1996. Imipramine treatment of alcoholics with primary depression: A placebo-controlled clinical trial. Arch. General Psychiatry, 53: 232-40.

McLean, E.Q. 1982. Soil pH and lime requirement. In: methods of soil analysis. R. H. Miller and D.R. keeney (Eds), Part 2, $2^{\text {nd }}$ Edn, agron.Monogr. No 9, SAS abs SSA, Madison WL Pp. 199-234.

Mohanty, S. and Satyasai, K.J. 2015. NABARD Rural Pulse, Feeling the Pulse Indian Pulses Sector. Department of Economic Analysis and Research, issue $\mathrm{x}$.

Mutanal, S.M. 1998. Studies on teak (Tectona grandis Linn.F.) based agroforestry system and fertigation. Ph.D. Thesis, Univ. Agric. Sci., Dharwad. (India).

Nadagoud, V.B. 1990. Performance of tree species and their influence on seasonal crops in agroforestry systems under irrigation. Ph.D. Thesis, Univ. Agric. Sci., Dharwad. (India).

Newman, E.I. 1997. Phosphorus balance of contrasting farming systems, past and present. Can food production be sustainable? J. Appl. Ecol., 34: 1334-47.

Ofuya, Z.M. and Akhidue, V. 2005. The role of pulses in human nutrition: A review. J. Appl. Sci. Environ. Management, 9: 99-104.

Olsen, S.R. and Sommers, L.E. 1982. Phosphorus.Pages 421-422 in method of soil analysis, part 2, chemical and microbiological properties.2nd ed. A. L. Page et al eds. ASA SSSA, Madison, Wisconsin, USA.

Padeyannavar, K.R. 2002, Physiological investigation on soybean [Glycine max (L.) Merrill] in agroforestry system. M.Sc. (Agri) Thesis, Univ. Agric.Sci., Dharwad. (India).

Pal, A., Kumar, P., Singh, R.P. and Kumar, P. 2014. Effect of different Phosphorus Levels on Urd Bean under Custard Apple based Agri-Horti System. J. Agri. Search, 1(1): 30-34.

Parameswarappa, S. 1995. Teak - how fast can it grow and how much can it pay? Indian Forester, 121(6): 563-565.

Patel, H.R., Patel, H.F., Maheriya, V.D. and Dodia, 
I.N. 2013. Response of kharif green gram (Vigna radita L. Wilczek) to sulphur and phosphorus fertilization with and without biofertilizer application. The Bioscan, 8(1): 149-152.

Patil, S.C., Jagtap, D.N. and Bhale, V.M. 2011. Effect of phosphorus and sulphur on growth and yield of moongbean. Int. J. Agri. Sci., 7: 348-351.

Prasad, S.K., Singh, M.K. and Singh, J. 2014. Response of Rhizobium Inoculation and Phosphorus Levels on mungbean (Vigna radiata) under Guava-based Agri-horti System.The Bioscan, 9(2): 557-560.

Rausch, C., Daram, P., Brunner, S., Jansa, J., Laloi, M., Leggewie, G. 2001. A Phosphate Transporter Ex- pressed in ArbusculeContaining Cells in Potato. Nature, 414: 462470.

Saha, J.K., Singh, A.B., Ganeshamurthy, A.N., Samaresh, K. and Biswas, A.K. 2001. Sulfur accumulation in Vertisols due to continuous gypsum application for six years and its effect on yield and biochemical constituents of soybean (Glycine maxL. Merrill). J. Plant Nutrition Soil Sci., 64: 317-20.

Salwa, A.I.E., Mohsen, M.A. and Behary, S.S. 2010. Amelioration productivity of sandy soil by using amino acid, $\mathrm{S}$ and micronutrients for sesame production. J. American Sci., 6: 25057.

Scherer, H.W. 2001. S in crop production - invited paper. European J. Agronomy, 14: 81-111.

Scherer, H.W. 2009. Sulfur in soils. J. Plant Nutri. Soil Sci., 172: 326-35.

Singh, B.P., Annette, L., Cowie, K. and Yin, C. 2011. Soil health and climate change, Soil Biology, (eds. Book). 29 Springer-Verlag
Berlin Heidelberg. Doi: 10.1007/978-3-64220256-8_4.

Singh, M.V. 2001. Importance of $\mathrm{S}$ balanced fertilizer use in India. Fertilizer News, 46: 1318.

Singh, S., and Kumar, P. 2012. Soil fertility status of vegetables growing areas of Varanasi and pulse growing areas of Mirzapur. J. Indian Soc. Soil Sci., 60: 233-36.

Subbiah, B.V., and Asija, G.L. 1956. A rapid procedure for the determination of available nitrogen in soils. Curr. Sci., 25: 259-60.

Tewatia, R.K., Choudhary, R.S. and Kalwe, S.P. 2007. Proceedings TSI-FAI-IFA Symposiumcum-Workshop-S in Balanced Fertilization, 4-5 October, 2006, New Delhi, The Fertilizer Association of India, New Delhi, 223 p.

Tisdale, S.L., Nelson, W.L., Beaton, J.D. and Havlin, J.L. 2003. Soil fertility and fertilizer (6th ed), Person Education (Singapore), Pvt. Ltd, New Delhi, India.

Tiwari, R.C., Namdeo, K. and Girisha, K.N. 2000.Effect of nitrogen and Sulphur on growth, yield and quality of sesame varieties. Res. Crops, 1:163-67.

Torquebiau, E. 2000. A renewed perspective on agroforestry concepts and classification. Comptes rendus de l'Académie des Sci/Life Sci., 323:1009-17.

Venkata, R.M., Patil, S.J. and Chetti, M.B. 2006. Morphological parameters and total biomass of groundnut as influenced by teak based agroforestry system. The Andhra Agric. J., 53(3 \& 4): 224-227.

Wild, A. 1988. Plant nutrients in soil: phosphate. In: Wild, A. (ed.) Russell's Soil Conditions and Plant Growth. Longman, Harlow, 695-74.

\section{How to cite this article:}

Jaiveer Singh Dhewa, Sameer Daniel and Sulochana. 2017. Effect of Different Levels of Phosphorus and Sulphur on Growth and Nutrient Uptake of Green gram (Vigna radiata L.) under Teak (Tectona grandis L.) based Agroforestry System. Int.J.Curr.Microbiol.App.Sci. 6(2): 520-534. doi: http://dx.doi.org/10.20546/ijcmas.2017.602.059 